\title{
THE EFFECT OF DIESEL FUEL ON COMMON VETCH (VICIA SATIVA L.) PLANTS
}

\author{
GILLIAN ADAM* and HARRY DUNCAN \\ Department of Environmental, Agricultural and Analytical Chemistry, Joseph Black Building, \\ University of Glasgow, Glasgow G12 8QQ, Scotland, UK (*author for correspondence: \\ Department of Chemistry, Scottish Universities Environmental Research Centre (SUERC), Scottish \\ Enterprise Technology Park, East Kilbride, G75 OQF, Scotland, UK; tel.: 01355 270 135; fax: \\ 01355229 898; e-mail: gilliana@chem.gla.ac.uk.)
}

Received 28 May 2001; accepted in revised form 28 October 2001

Environmental Geochemistry and Health 25: 123-130, 2003.

\begin{abstract}
When petroleum hydrocarbons contaminate soil, the carbon:nitrogen $(\mathrm{C}: \mathrm{N})$ ratio of the soil is altered. The added carbon stimulates microbial numbers but causes an imbalance in the $\mathrm{C}: \mathrm{N}$ ratio which may result in immobilization of soil nitrogen by the microbial biomass, leaving none available for plant growth. As members of Leguminosae fix atmospheric nitrogen to produce their own nitrogen for growth, they may prove more successful at growing on petroleum hydrocarbon contaminated sites. During a wider study on phytoremediation of diesel fuel contaminated soil, particular attention was given to the performance of legumes versus other plant species. During harvesting of pot experiments containing leguminous plants, a recurring difference in the number and formation of root nodules present on control and contaminated Common vetch (Vicia sativa L.) plants was observed. The total number of nodules per plant was significantly reduced in contaminated plants compared to control plants but nodules on contaminated plants were more developed than corresponding nodules on control plants. Plant performance of Common vetch and Westerwold's ryegrass (Lolium multiflorum L.) was compared to illustrate any difference between the ability of legumes and grasses to grow on diesel fuel contaminated soil. Common vetch was less affected by diesel fuel and performed better in low levels of diesel fuel contaminated soil than Westerwold's ryegrass. The total amount of diesel fuel remaining after 4 months in Common vetch planted soil was slightly less than in Westerwold's ryegrass planted soil.
\end{abstract}

Key words: Common vetch, diesel fuel, legumes, phytoremediation, plant performance, root nodules, Westerwold's ryegrass

\section{Introduction}

One factor known to limit the growth of higher plants is the availability of nitrogen in the soil (Greirson and Covey, 1988).When petroleum hydrocarbons contaminate soil, the added carbon stimulates microbial numbers and causes an imbalance in the $\mathrm{C}: \mathrm{N}$ ratio which may result in 
immobilization of soil nitrogen by the microbial biomass, leaving none available for plant growth (Xu and Johnson, 1997). Members of Leguminosae fix atmospheric nitrogen to produce their own nitrogen for growth, therefore, they overcome this limitation and may prove more successful at growing on petroleum hydrocarbon contaminated sites. The interaction of leguminous plants with nitrogen-fixing bacteria results in increased microbial biomass in the root zone (rhizosphere), plant growth and root exudation which may in turn lead to enhanced microbial degradation of organic compounds, such as petroleum hydrocarbons, in the rhizosphere (Anderson et al., 1993). To further support this statement, species of Leguminosae have been found to be the most abundant reinhabitors of petroleum hydrocarbon contaminated sites (Gudin and Syratt, 1975).

During a wider study on the phytoremediation of diesel fuel contaminated soil, particular attention was given to the performance of legumes versus other plant species. An important factor of the legumes' success would be dependent on the development of root nodules. Decrease in nodule formation has been noted in soils contaminated with heavy metals (Porter and Sheridan, 1981; Casella et al., 1988), agrochemicals (Mårtensson, 1992), polyaromatic hydrocarbons (PAHs) (Wetzel and Werner, 1995) and in soils receiving acidic deposition (Porter and Sheridan, 1981). However, to the best of our knowledge, no work has been carried out on nodulation in diesel fuel contaminated soil. The present study investigates nodule formation on Common vetch plants grown in diesel fuel contaminated soil. Plant performance of Common vetch andWesterwold's ryegrass is compared to illustrate any difference between the ability of legumes and grasses to grow on diesel fuel contaminated soil.

\section{Materials and methods}

\subsection{PLANT GROWTH EXPERIMENTS}

The pot trial involved growing Vicia sativa L. (common name Common vetch) and Lolium multiflorum L. (common name Westerwold's ryegrass) plants plus a control with no plants at four different diesel fuel treatment levels $\left(0,5,10\right.$ and $15 \mathrm{~g}$ diesel $\mathrm{kg}^{-1}$ soil). The trial incorporated three replicate pots per treatment and two sampling dates at 2 and 4 months growth. Diesel fuel contaminated soil was prepared by accurately weighing the appropriate amount of diesel fuel into a 4-oz glass jar then pouring the diesel fuel over $2 \mathrm{~kg}$ of John Innes compost (textural class: sand (72.2\% coarse sand, $17.6 \%$ fine sand, $4.9 \%$ silt and $8.4 \%$ clay), $10.2 \%$ organic matter content (LOI\%) and $0.19 \%$ Kjeldahl nitrogen content). Diesel fuel was obtained from a local petrol station. The diesel fuel was mixed thoroughly through the soil using a hand trowel then the contaminated soil was transferred to labelled, 7" plastic pots ready for planting. Twenty Common vetch orWesterwold's ryegrass seeds were planted per pot and the pots watered and covered with black plastic sheeting to aid germination and prevent the surface soil from drying out. After 4 days, when the majority of seeds were showing signs of germinating, the covering was removed and light was provided by a central lamp (Phillips 400 watt HP 1 plus) set on a $16 \mathrm{~h}$ light/8 h dark cycle.

\subsection{AGRONOMIC ASSESSMENT}

Germination rate, tallest shoot height and total shoot and root biomass were measured after 2 and 4 months growth. The number of root nodules per plant was assessed at the 2 month sampling date and Tukeys One-Way Analysis of Variance test (Minitab) used to indicate whether or not there was a significant difference between treatment means. 


\subsection{ROOT NODULE EMBEDDING AND MICROSCOPY}

Plants were shaken free from soil and washed thoroughly under running water. After the root sample was washed, the number of nodules was determined on a per plant basis. The freshly washed root nodules were then fixed in $2.5 \%$ gluteraldehyde in $0.2 \mathrm{M}$ cacodylate buffer for $6 \mathrm{~h}$ then dehydrated through an ethanol series. The dehydrated nodules were then infiltrated with LR white resin for $48 \mathrm{~h}$ and polymerized at $60{ }^{\circ} \mathrm{C}$ overnight. Sections $(2 \mu \mathrm{m})$ were cut using a glass knife on an LKB ultratone III and dried onto glass slides over a hotplate at $60{ }^{\circ} \mathrm{C}$. The sections were stained for $10 \mathrm{~s}$ with $1 \%$ toluidine blue in $1 \%$ sodium tetraborate and visualized at $40 \times$ and $100 \times$ magnification on a Leica ATCTM 2000 compound microscope with digital camera attachment.

\subsection{DIESEL FUEL EXTRACTION}

Diesel fuel in soils at time zero and that remaining in the soil after 4 months was extracted using a hot solvent soxhlet extraction modified from the US EPA method $3540 \mathrm{C}$ for non-volatile and semivolatile organic compounds (US EPA, 1986) and the method of Song et al. (1990). Forty grams of soil sample was added to a cellulose extraction thimble containing $5 \mathrm{~g}$ anhydrous sodium sulphate then extracted for $6 \mathrm{~h}$ in $100 \mathrm{~mL}$ of acetone:dichloromethane $(1: 1 \mathrm{v} / \mathrm{v})$. The extract was transferred to a $100 \mathrm{~mL}$ volumetric flask and made to volume with acetone:dichloromethane $(1: 1 \mathrm{v} / \mathrm{v})$.

\subsection{GC-FID ANALYSIS OF EXTRACTS}

Analyses of the extracts were carried out on a Hewlett-Packard 5890A gas chromatograph with flame ionization detector (GC-FID). The GC was interfaced with a Hewlett-Packard Chemstation data system. Helium carrier gas was adjusted to the recommended linear flow velocity of $20 \mathrm{~cm} \mathrm{~s}^{-1}$ using the non-retained compound butane. Separations were performed on an SGE BPX5 polysilphenylene siloxane capillary column $(25 \mathrm{~m} \times 0.32 \mathrm{~mm} \times$ I.D. $0.5 \mu \mathrm{m}) .0 .5 \mu \mathrm{L}$ of sample was injected at $35{ }^{\circ} \mathrm{C}$ with a temperature hold of $3 \mathrm{~min}$. The temperature was increased $5{ }^{\circ} \mathrm{Cmin}^{-1}$ up to $250{ }^{\circ} \mathrm{C}$ with a $10 \mathrm{~min}$ hold at the end of the run. The injector temperature was $260^{\circ} \mathrm{C}$ and the detector temperature was $270 \circ \mathrm{C}$.

Percentage of diesel fuel remaining in the soil after 4 months was calculated from the total petroleum hydrocarbon (TPH) value of each sample extracted from the soils after 4 months subtracted from the TPH value of diesel fuel extracted from the soil at time zero. TPH values were calculated from the total peak areas of triplicate injections with less than $5 \%$ difference between them.

\section{Results and discussion}

During harvesting of pot experiments containing leguminous plants, a recurring difference in the number and formation of root nodules present on control ( $0 \mathrm{~g}$ diesel $\mathrm{kg}^{-1}$ soil) and diesel fuel contaminated Common vetch plants was observed. The average total number of nodules per plant was significantly reduced in contaminated plants compared to control plants, with numbers falling from eight ( \pm 1.0 standard error $(\mathrm{SE}), n=14$ ) nodules per plant in the controls, to 3 ( $\pm 0.7(\mathrm{SE}), n=$ 14), 4 ( $\pm 0.8(\mathrm{SE}), n=17)$ and $<1(n=13)$ in the 5,10 and $15 \mathrm{~g}$ diesel $\mathrm{kg}^{-1}$ contaminated soil, respectively. 
Observation of nodule sections by light microscopy illustrated clear differences between nodules of control Common vetch plants and plants grown in diesel fuel contaminated soil. The majority of nodules from control plants were spherical and appeared to be at the initial stages of nodule differentiation. Few bacteroids were present within the central body of the nodule suggesting the nodule was immature and would therefore not be effectively fixing atmospheric $N_{2}$ (Figures $1(A)$ and (B)). Nodules taken from contaminated plants were elongate or club-shaped and the central mass of tissue showed successive stages of host cell invasion and differentiation by rhizobium. The bacteroids were numerous and filled most of the central nodule body as illustrated in Figures 1(C) and (D). The results suggest at low levels of diesel fuel contamination (5-10 g diesel $\mathrm{kg}-1$ soil), nodules formed on contaminated plants are actually more developed than the corresponding nodules on control plants. This finding is in agreement with Carr (1919) who first noted the apparent stimulation of legume root nodules by low levels of hydrocarbon contamination on Soybean plants. Carr (1919) concluded that small amounts of oil may even be desirable in nodule development in Soybean plants and where the amount of oil was increased to the extent of damaging the plant, there was still some nodule development. An explanation for the apparent stimulation of nodule development in diesel fuel contaminated soil may be the additional carbon added to the soil in the form of diesel fuel, changed the soils $\mathrm{C}: \mathrm{N}$ ratio. The addition of a huge carbon source, such as diesel fuel, would widen the $\mathrm{C}: \mathrm{N}$ ratio which in turn, would leave less $\mathrm{N}$ available for plant uptake. This has been observed in soils contaminated with petroleum hydrocarbons (Xu and Johnson, 1997) with $N$ becoming immobilized in microbial biomass leaving less $\mathrm{N}$ available for plant uptake. Leguminous plants have overcome this limitation to growth by forming a highly organized association with nitrogen fixing bacteria (rhizobia). These soil-borne bacteria are stimulated to invade the roots of susceptible plants by the release of specific chemical signals from the plant root. The bacteria form intracellular 'organelles', called bacteroids that convert atmospheric nitrogen to ammonia for assimilation by the plant. These bacteroids are housed in root nodules that provide the appropriate environment and nutrients to support nitrogen fixation (Greirson and Covey, 1988). The lack of plant available nitrogen may be the reason why Common vetch plants growing in contaminated soil nodulated more quickly than plants grown in uncontaminated soil. This would in turn explain why contaminated nodules appeared more developed and at a later stage of differentiation than control nodules even though the seeds were planted at the same time.

When the agronomic performance of Common vetch plants was compared with a non-leguminous species such as Westerwold's ryegrass (Table I), a number of differences were observed. Percentage germination results were very similar for both plant species in $0-10 \mathrm{~g}$ diesel $\mathrm{kg}^{-1}$ soil treatment levels. At the $15 \mathrm{~g}$ diesel $\mathrm{kg}^{-1}$ soil treatment level, a decrease in germination rate was observed, with a larger decrease in percentage germination being seen for Westerwold's ryegrass. Average shoot biomass for plants grown in 5-10 g diesel $\mathrm{kg}-1$ contaminated soil was higher for Common vetch than Westerwold's ryegrass. However, average root biomass was higher for Westerwold's ryegrass than Common vetch at all diesel fuel treatment levels. Although shoot height was not badly affected by growing in 5-10 g diesel kg-1 contaminated soil in either plant species, the larger decrease in shoot biomass observed for Westerwold's ryegrass suggests a deterioration in plant health and performance. 
(A)

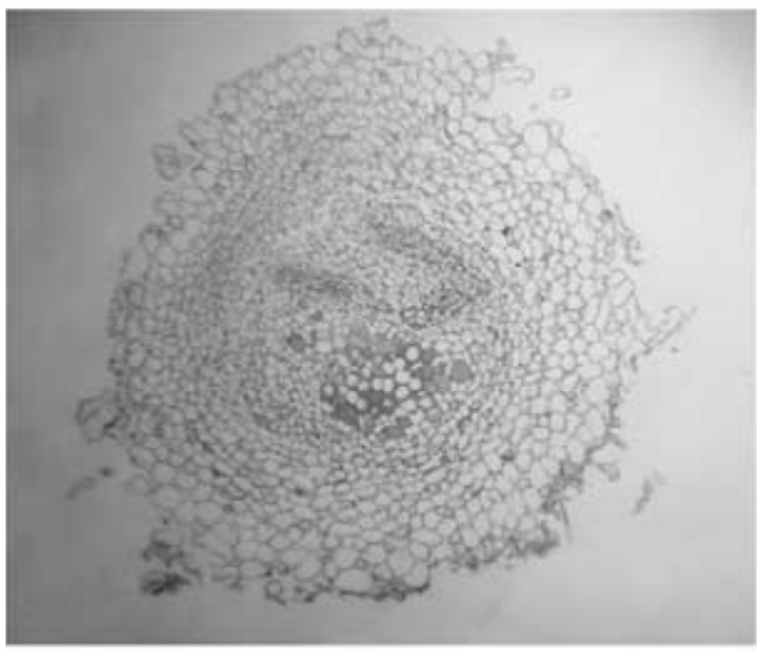

(C)

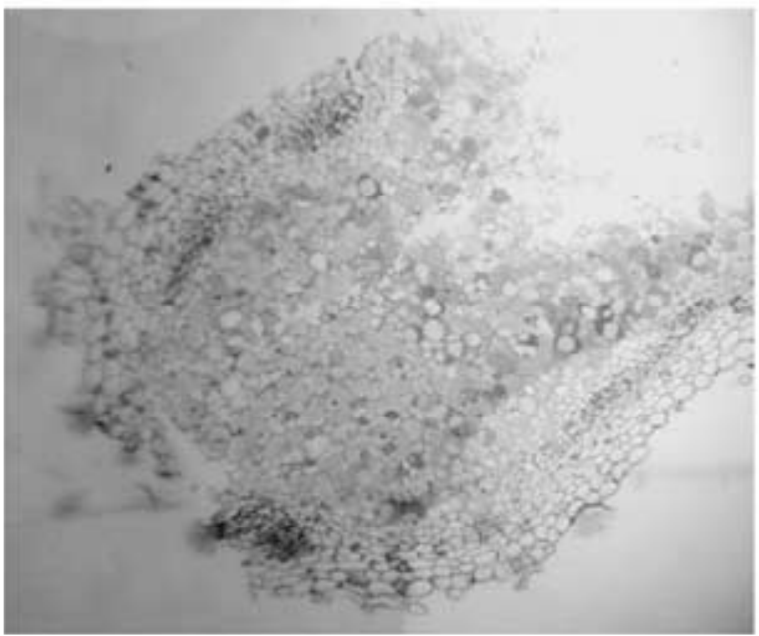

(B)

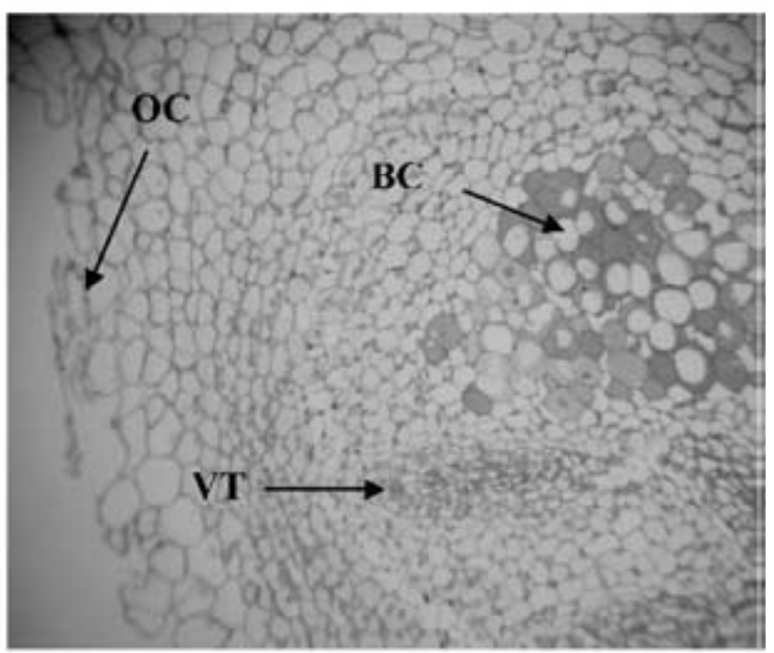

(D)

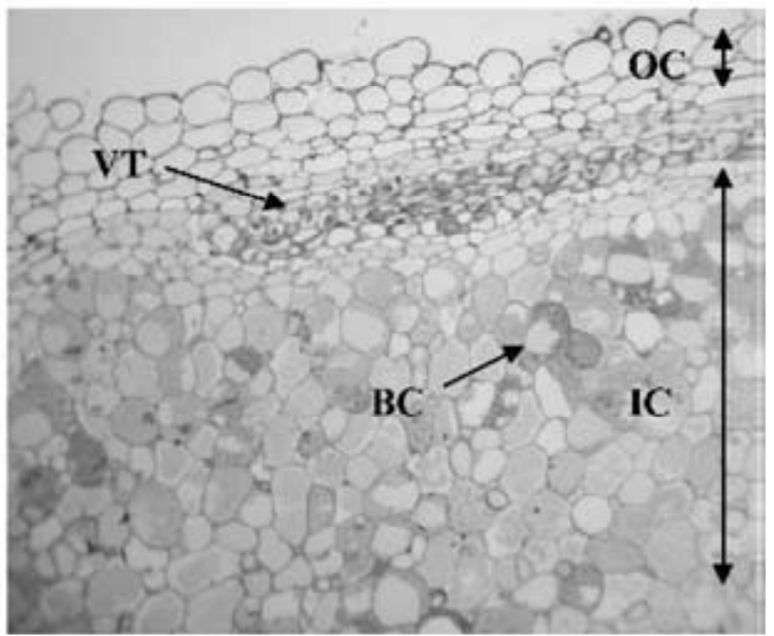

Figure 1. Light microscopy section $(2 \mu \mathrm{m})$ of a Common vetch nodule grown in uncontaminated soil (magnification $\times 40)(A)$, enlargement of this nodule $(\times 100)(B)$, nodule grown in diesel fuel contaminated soil ( $5 \mathrm{~g}$ diesel $\mathrm{kg}-1$ soil) $(\times 40)(\mathrm{C})$ and enlargement of this nodule $(\times 100)(\mathrm{D})$. VT vascular tissue; $\mathrm{BC}$ - bacteroid cluster; OC - outer cortex; IC - inner cortex. 
TABLE I

Summary of agronomic assessment and diesel fuel breakdown in Common vetch and Westerwold's ryegrass planted soils after 4 months ${ }^{\mathrm{a}}$

\begin{tabular}{|c|c|c|c|c|c|c|}
\hline Plant Species & $\begin{array}{l}\text { Treatment (g diesel } \\
\mathrm{kg}^{-1} \text { soil) }\end{array}$ & Germination (\%) & $\begin{array}{l}\text { Average shoot } \\
\text { biomass per plant } \\
\text { (mg) }\end{array}$ & $\begin{array}{c}\text { Average root } \\
\text { biomass per plant } \\
(\mathrm{mg})\end{array}$ & $\begin{array}{l}\text { Tallest shoot length } \\
(\mathrm{cm})\end{array}$ & $\begin{array}{l}\text { \% diesel fuel } \\
\text { remaining }\end{array}$ \\
\hline \multirow[t]{3}{*}{ Common vetch } & 0 & $55 \pm 6$ & $1230 \pm 84$ & $55 \pm 15$ & $64 \pm 3$ & \\
\hline & 10 & $60 \pm 8$ & $552 \pm 31$ & $49 \pm 8$ & $56 \pm 5$ & 1.58 \\
\hline & 15 & $48 \pm 4$ & $123 \pm 50$ & $24 \pm 18$ & $39 \pm 7$ & 1.90 \\
\hline Westerwold's & 0 & $55 \pm 2$ & $1388 \pm 49$ & $55 \pm 2$ & $79 \pm 4$ & \\
\hline ryegrass & 5 & $62 \pm 6$ & $667 \pm 2$ & $62 \pm 6$ & $75 \pm 8$ & nd \\
\hline
\end{tabular}

\footnotetext{
${ }^{a}$ Average values are given \pm standard error, $n=3$. Values indicating \%diesel fuel remaining had $<5 \%$ difference between replicate areas, $n=3$.
} 
The total amount of diesel fuel remaining after 4months in Common vetch planted soil was slightly less than inWesterwold's ryegrass planted soil (Table I). The enhanced degradation of diesel fuel observed under Common vetch planted soil coupled to it's superior plant performance suggests Common vetch may be a successful plant species to use in the phytoremediation of diesel fuel contaminated soil.

\section{Conclusion}

Despite the reduction in the number of root nodules found on Common vetch plants grown in diesel fuel contaminated soil compared to plants grown in uncontaminated soil, nodules found on contaminated plants were more developed than corresponding nodules on control plants. Nodules on control plants were small and immature whereas nodules found on plants grown in diesel fuel contaminated soil were large and showed successive stages of cell differentiation. Germination rate appeared unaffected in both plant species up to the $15 \mathrm{~g}$ diesel $\mathrm{g}^{-1}$ contaminated soil level where a larger decrease in germination rate was observed for Westerwold's ryegrass when compared with Common vetch plants. Although shoot height was not badly affected by growing in $5-10 \mathrm{~g}$ diesel $\mathrm{kg}^{-1}$ contaminated soil in either plant species, the larger decrease in shoot biomass observed for Westerwold's ryegrass suggested a deterioration in plant health and performance. Overall, the results suggest Common vetch was generally less affected by diesel fuel and performed better in low levels of diesel fuel contaminated soil than Westerwold's ryegrass. This advantage over Westerwold's ryegrass may have been due to the presence of well-developed root nodules on the contaminated plants.

\section{Acknowledgements}

We would like to thank Mr Eoin Robertson of the IBLS Electron Microscopy Unit, University of Glasgow, for preparation of the root nodule sections for microscopic examination and Mr Michael Beglan, Department of Environmental, Agricultural and Analytical Chemistry, University of Glasgow, for his help in photographing the sections. The authors would also like to thank Dr Euan James of the University of Dundee and Dr Pietro lannetta of the Scottish Crop Research Institute for useful discussions regarding root nodule structure.

\section{References}

Anderson, T.A., Guthrie, E.A. and Walton, B.T.: 1993, Bioremediation, Environmental Science and Technology 27, 2630-2636.

Carr, R.H.: 1919, Vegetative growth in soils containing crude petroleum, Soil Science 66-69. Casella, S., Frassinetti, S., Lupi, F. and Squartini, A.: 1988, Effect of cadmium, chromium and copper on symbiotic and free living Rhizobium leguminosarum biovar trifolii, FEMS Microbiology Letters 49, 343-347.

US EPA: 1986, Method 3540C non-volatile and semi-volatile organic compounds, www.epa.gov. Greirson, D. and Covey, S.: 1988, Gene expression during development of nitrogen-fixing root nodules, in: Plant Molecular Biology, 2nd edn, Blackie and Son Ltd., Glasgow.

Gudin, C. and Syratt, W.J.: 1975, Biological aspects of land rehabilitation following hydrocarbon contamination, Environmental Pollution 8, 107-112. 
Mårtensson, A.M.: 1992, Effects of agrochemicals and heavy metals on fast growing rhizobia and their symbiosis with small-seeded legumes, Soil Biology and Biochemistry 24, 435-445.

Porter, J.R. and Sheridan, R.P.: 1981, Inhibition of nitrogen fixation in alfalfa by arsenate, heavy metals, fluoride and simulated acid rain, Plant Physiology 68, 143-148.

Song, H.G.,Wang, X. and Bartha, R.: 1990, Bioremediation potential of terrestrial fuel spills, Applied and Environmental Microbiology 56(3), 652-656.

Wetzel, A. andWerner, D.: 1995, Ecotoxicological evaluation of contaminated soil using legume root nodule symbiosis as effect parameter, Environmental Toxicology and Water Quality 10, 127-133.

Xu, J.G. and Johnson, R.L.: 1997, Nitrogen dynamics in soils with different hydrocarbon contents planted to barley and field pea, Canadian Journal of Soil Science 77, 453-458. 